\title{
Phyto-Nutrient Diversity in Morinda Citrifolia L. Genotypes of Andaman Islands, India
}

\author{
Singh $\mathrm{DR}^{*}$, Singh S and Banu VS
}

Division of Horticulture and Forestry, Central Island Agricultural Research Institute, Port Blair, Andaman and Nicobar Islands, India

${ }^{*}$ Corresponding author: Singh DR, Division of Horticulture and Forestry, Central Island Agricultural Research Institute, Post Box No. 181, Garacharma (Post), Port Blair, Andaman and Nicobar Islands - 744101, India, E-mail: drsinghhort66@gmail.com

Citation: Singh DR, Singh S, Banu VS (2017) Phyto-Nutrient Diversity in Morinda Citrifolia L. Genotypes of Andaman Islands, India. J Hematol Blood Disord 3(1): 103. doi: 10.15744/2455-7641.3.103

Received Date: December 16, 2016 Accepted Date: August 15, 2017 Published Date: August 17, 2017

\begin{abstract}
The Indian mulberry or Noni (Morinda citrifolia L.) is one of the emerging sources of natural antioxidants for herbal and pharmaceutical industry. The genus Morinda has more than 150 species in which M. citrifolia is identified as most important for health and economic point of view. Present study revealed significant $(\mathrm{p}<0.05)$ diversity in 33 genotypes of $M$. citrifolia from Andaman and Nicobar Islands (India) for phyto-constituents. The promising genotypes viz. FRG-14, JGH-5, TRA-1, TRA-2 and HD-6 were identified for commercial uses. Correlation analysis in M. citrifolia germplasm showed strong correlation between carotenoids and ascorbic acid $\left(\mathrm{r}^{2}=0.973\right.$; $\mathrm{p}<0.05)$, tannin $\left(\mathrm{r}^{2}=0.598 ; \mathrm{p}<0.05\right)$, flavonoids $\left(\mathrm{r}^{2}=0.691 ; \mathrm{p}<0.05\right)$ and phenol $\left(\mathrm{r}^{2}=0.598 ; \mathrm{p}<0.05\right)$. The genotypes showed wide range for antioxidant capacity which showed positive correlation with carotenoids $\left(r^{2}=0.335 ; \mathrm{p}<0.05\right)$, flavonoids $\left(\mathrm{r}^{2}=0.249 ; \mathrm{p}<0.05\right)$ and $\mathrm{Cu}\left(\mathrm{r}^{2}\right.$ $=0.953 ; \mathrm{p}<0.05), \mathrm{Mn}\left(\mathrm{r}^{2}=0.953 ; \mathrm{p}<0.05\right)$ and $\mathrm{Mg}\left(\mathrm{r}^{2}=0.582 ; \mathrm{p}<0.05\right)$. The diversity analysis is useful for designing breeding strategies for phyto-nutrient rich genotypes for better recovery in health products.
\end{abstract}

Keywords: Phytochemicals; Micronutrients; DPPH activity; Pharmaceutical industry; Morinda citrifolia

\section{Introduction}

Now-a-days, natural antioxidants are much talked compounds for their health benefits. Noni (Morinda citrifolia L.; Rubiaceae) is an underexplored phyto-nutrient rich medicinal plant from tropical region [1]. It is a small evergreen tree or shrub, bears lumpy, green to yellowish-white fruits. Morinda fruits (Figure 1) have been used in different traditional health systems of Nicobarese, Chinese, Australians and Polynesians [2]. It is native of Andaman \& Nicobar and adjoining regions in Indian Ocean and distributed to other regions of the Indian and Pacific Oceans [3]. Around 150 species were reported in genus Morinda which spread across the India, Pacific and tropical island regions and Morinda citrifolia L. is most commonly used species in herbal and pharmaceutical industry $[1,4]$. The M. citrifolia is also used for traditional medicine, roasted food and fried vegetable by primitive tribes of Andaman and Nicobar Islands [5].

Researchers reported around 200 phyotochemicals including phenolics, carotenoids, polysaccharides, flavonoids, iridoids, fatty acids, scopoletin, catechin, beta-sitosterol, damnacanthal and alkaloids [3,6]. These compounds contribute in number of biological activities such as anti-angiogenesis, antioxidant, cyclooxygenases- 1 and - 2 inhibition and tyrosine kinase inhibition and curing simple to complex ailments such as arthritis, diabetes, high blood pressure, muscle aches, menstrual difficulties, headaches, heart disease, immunodeficiency, cancer, gastric ulcers, sprain, mental depression, senility, poor digestion, atherosclerosis, blood vessel problems and drug addiction $[3,4,6]$.

These compounds contribute in free radical scavenging capacity of plant extracts but their kind and concentration varies among plant species or their genotypes [2,7,8]. Further, morphological and genetic diversity in Morinda germplasm could affect physiological processes, resultantly phyto-nutrient diversity in $M$. citrifolia $[9,10]$. Thus, information on such diversity in $M$. citrifolia was essential for developing genotypes with higher recovery of antioxidants and micronutrients in Morinda based herbal and pharmaceutical products. Therefore, present study conducted to analyze diversity in M. citrifolia for phyto-nutrients and to find correlation between such compounds for use in further breeding programme. 


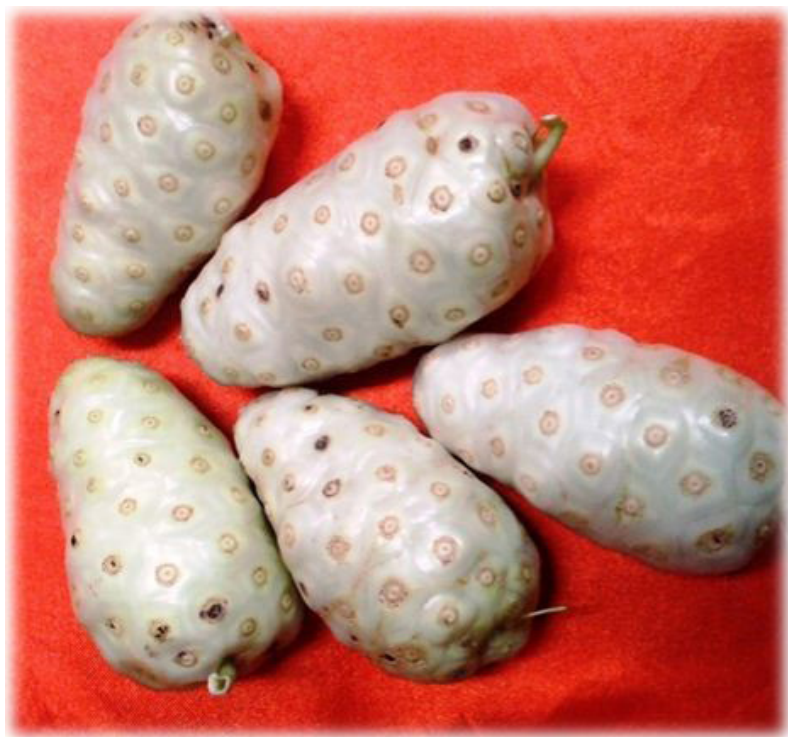

Figure 1: Ripe fruits of Morinda citrifolia L. ('HD-6')

\section{Materials and Methods}

\section{Sample collection and preparation}

Fresh healthy mature fruits of 33 genotypes of Morinda citrifolia L. were collected from Noni Germplasm Block, Central Island Agricultural Research Institute, Port Blair, Andaman and Nicobar Islands, India. Sample preparation for phytochemicals and antioxidant activity estimation was done as per the procedure described by Singh, et al. (2012a) with minor modifications. In brief, $2 \mathrm{~g}$ sample from homogenized fruit pieces were ground in $10 \mathrm{ml}$ methanol in mortar and pestle till sample become colorless [8]. The extract was centrifuged (Heraeus Biofuge, Taylor Scientific Pvt. Ltd., Missouri) at $8000 \times \mathrm{g}$ for $10 \mathrm{~min}$ and filtered through Whatman No. 1 filter paper. It was concentrated by rotary evaporator (Cyper Lab Corp., Millburg, USA) and kept in -20 ${ }^{\circ} \mathrm{C}$ for further analysis. Sample for anthocyanin estimation were prepared in Methanol: Formic acid: Water (70:2:28) solution. Carotenoid estimation was done with $80 \%$ acetone extract while $4 \%$ oxalic acid was used for Ascorbic acid estimation.

\section{Phytochemical estimation}

Total polyphenol content in fruit samples of M. citrifolia was determined by Folin-Ciocalteau reagent method (10\%, v/v) with gallic acid as standard (mg/100 g fresh weight) and taking absorbance at $765 \mathrm{~nm}$ by UV-spectrophotometer (Elico SL-164, Pvt Ltd, Hyderabad, India). Flavonoid content was determined using the procedure described by Chang, et al. (2002) and expressed as $\mathrm{mg}$ rutin equivalent $(\mathrm{mg} / 100 \mathrm{~g}$ fresh weight) [11,12]. The $\mathrm{pH}$ differential method was used for anthocyanin estimation and concentration was expressed as mg cyanidine-3-glucoside (C3GE) /100g fresh weight. Ascorbic acid, tannin and total carotenoids were estimated using standard volumetric methods described by $[13,14]$.

\section{DPPH antioxidant activity}

The hydrogen atom or electron-donation ability of $M$. citrifolia fruit extracts was determined using 1,1-diphenyl-2-picrylhydrazyl radical (DPPH) as per procedure described by Singh, et al. (2012a) in underutilized fruits. In brief, 0.1 ml methanolic extract of fruit added to $3 \mathrm{ml}$ of $0.001 \mathrm{M}$ DPPH methanol solution and took absorbance at $517 \mathrm{~nm}$ using UV-visible spectrophotometer (Elico Pvt., Hyderabad, India) after $30 \mathrm{~min}$ of incubation period [8]. The per cent inhibition of activity was calculated using the standard formula: $[(\mathrm{Ao}-\mathrm{Ae}) / \mathrm{Ao}] \times 100$ (Ao, absorbance without extract; Ae, absorbance with extract).

\section{Proximate composition}

Carbohydrate and acidity in fruits from 33 genotypes were estimated by process described by Sadasivam and Manikam (1996) [15]. Crude protein was determined by formula, $\mathrm{CP}(\%)=\mathrm{N} \times 6.25$; where $\mathrm{N}$ is total nitrogen in fruits estimated by digestion and distillation units. Fat content in fruits was estimated by soxlet apparatus crude fibre content was estimated by acid-base digestion method and total soluble solids in the fruits were determined by refractometer (PAL 1, Atago, Tokyo Tech., Japan) [15,16].

\section{Anti-nutritional factors}

Phytate, oxalate and nitrate content in fruits of $M$. citrifolia genotypes were determined by the procedure described by Hassan, et al. (2008) while saponin content was estimated as per AOAC (1995) method [16,17].

\section{Micronutrient estimation}

Magnesium, calcium, copper and manganese content in fruits of 33 genotypes of $M$. citrifolia were determined through Atomic 
Absorption Spectrophotometer (AAS; Shimandzu AA 6200). For this, the sample were converted into ash by muffle furnace and dissolved in millipore water and the samples were then diluted to a suitable volume.

\section{Statistical analysis}

The observed data were analysed for mean, STDEV and range using EXCEL software 2007. Pearson correlation coefficient for phyto-nutrients was tested for significance $(\mathrm{P}<0.05 ; \mathrm{P}<0.01)$ using WINKS SDA software.

\section{Results and Discussions}

\section{Phytochemical contents}

Phytochemicals are important bioactive compounds from plant kingdom and play key role in human health and food. Now-a-days, it has been accepted that the natural bio-actives such as phenolics, carotenoids, flavonols, ascorbic acid, tannin, anthraquinones and anthocyanin are key factors for longevity. They neutralize, scavenge or inhibit the free radicals generated as by-products of biochemical reactions in body. However, their concentration in plants is affected by genetic, environmental and estimation methods and researchers identified phytochemical rich plant sources $[2,8,18]$.

The results for phytochemical contents in 33 genotypes of Morinda citrifolia showed great extent of diversity as summarized in Table 1. The M. citrifolia was reported as one of the richest source of natural antioxidants which is supported by the findings of present study $[6,8]$.

\begin{tabular}{|c|c|c|c|c|c|c|c|c|c|c|c|}
\hline Genotypes* & $\begin{array}{c}\begin{array}{c}\text { Poly- } \\
\text { phenol }\end{array} \\
(\mathrm{mg} / 100 \mathrm{~g})\end{array}$ & $\begin{array}{l}\text { Flavonoid } \\
(\mathrm{mg} / 100 \mathrm{~g})\end{array}$ & $\begin{array}{c}\text { Tannin } \\
(\mathrm{mg} / 100 \mathrm{~g})\end{array}$ & $\begin{array}{c}\text { Antho- } \\
\text { cyanin } \\
(\mathrm{mg} / 100 \mathrm{~g})\end{array}$ & $\begin{array}{c}\text { Carot- } \\
\text { enoid } \\
(\mathrm{mg} / 100 \mathrm{~g})\end{array}$ & $\begin{array}{c}\text { Ascor- } \\
\text { bic acid } \\
(\mathrm{mg} / 100 \mathrm{~g})\end{array}$ & $\begin{array}{c}\text { Anti- } \\
\text { oxidant } \\
\text { Activity } \\
\text { (DPPH) } \\
(\%)\end{array}$ & $\begin{array}{l}\text { Nitrate } \\
(\mathrm{mg} / 100 \mathrm{~g})\end{array}$ & $\begin{array}{l}\text { Phytate } \\
(\mathrm{mg} / 100 \mathrm{~g})\end{array}$ & $\begin{array}{c}\text { Oxalate } \\
(\mathrm{mg} / 100 \mathrm{~g})\end{array}$ & $\begin{array}{l}\text { Saponin } \\
(\mathrm{mg} / 100 \mathrm{~g})\end{array}$ \\
\hline Average & 261.8 & 344.1 & 236 & 248.3 & 455.2 & 85.1 & 62.89 & 18.2 & 239 & 9.2 & 88.3 \\
\hline STDEV & 58.8 & 166.4 & 72.9 & 37.9 & 142.4 & 7.1 & 11.64 & 59 & 619.4 & 49.5 & 258.5 \\
\hline Range & $58.8-370.3$ & $47.8-656.2$ & $72.9-395.2$ & $37.9-340.4$ & $\begin{array}{c}114.7- \\
696.3\end{array}$ & $7.1-98.2$ & $11.6-88.6$ & $18.2-98.8$ & $\begin{array}{c}185.1- \\
968.0\end{array}$ & $9.2-67.1$ & $88.3-440.0$ \\
\hline
\end{tabular}

Table 1: Statistics of phytochemical diversity in Morinda citrifolia L. genotypes

Total polyphenol content in fresh fruits of genotypes was ranged from $165.40 \mathrm{mg} / 100 \mathrm{~g}$ ('MBAY-6') to $370.26 \mathrm{mg} / 100 \mathrm{~g}$ (in 'TRA1'). The 'CHTAP-13', 'HD-6' and 'HD-6A' also found to be rich in polyphenol. Morinda fruits were rich source of flavonoids and present study observed significant $(\mathrm{p}<0.05)$ diversity among the tested genotypes of $M$. citrifolia [14]. It ranged from 47.57 to 656.18 $\mathrm{mg} / 100 \mathrm{~g}$, maximum in 'JGH-5' while minimum in 'CHTAP-13' while other genotypes rich in flavonoid content were 'TRA-1', 'PBAY-7', 'TRA-2' and 'JGH-1'. The significant variations in M. citrifolia genotypes for phyto-nutrients could be due to genetic variations as deoxyribonucleic acid (DNA) which was reported by Singh, et al. (2011a; 2013) [9,19]. Here, the DNA play crucial role in regulating the transcription and translation processes associated with the enzymatic activities for synthesis of secondary metabolites in cell system [20].

Tannin contribute in strong free radical activity of plant extracts and present study showed wide variation among the genotypes of M. citrifolia for its concentration in fresh fruits which ranged from $88.92 \mathrm{mg} / 100 \mathrm{~g}$ in 'MEM-3' to $395.20 \mathrm{mg} / 100 \mathrm{~g}$ in 'HD-6'. Other tannin rich genotypes were 'TRA-1', 'CHTAP-13', 'HD-6A', 'JGH-1' and 'JGH-5' [18]. Morinda was reported as poor source of anthocyanin but difference could observe in present study which showed it range from $163.25 \mathrm{mg} / 100 \mathrm{~g}$ ('MEM-3') to 340.39 mg/100 g ('MANJ-1') [8]. Total carotenoids are crucial factor for antioxidant activity of the plant extracts and existing diversity of $M$. citrifolia showed an opportunity for selection of carotenoid rich genotypes for use in breeding programme [18]. The study showed wide variation among $M$. citrifolia genotypes for carotenoid content which ranged from 114.68 to $696.26 \mathrm{mg} / 100 \mathrm{ml}$, with 'LH-12', 'AHD-1', 'TRA-2', 'MEM-2' and 'WAND-4' as carotenoid rich genotypes. However, M. citrifolia genotypes did not show significant $(\mathrm{p}<0.05)$ variations for ascorbic acid content which ranged from 71.0 (MBAY-16) to 98.20mg/100g (GAH-1). Thus, identified genotypes could help in breeding of phyto-nutrient genotypes as well as in higher recovery of phytochemicals from same quantum of fruits.

\section{DPPH Antioxidant activity}

The phytochemical constituents exhibit their free radical scavenging capacity during in vitro studies $[6,8,18]$. Similarly, the fruit extract from 33 genotypes of $M$. citrifolia showed great variation in DPPH activity (Table 1). The genotypes showed high antioxidant activities were identified as 'GAH-1' $\left(92.23 \%\right.$; $\left.\mathrm{IC}_{50}=114.57 \mu \mathrm{g} / \mathrm{ml}\right)$ and 'HD-6' $\left(88.83 \%\right.$; $\left.\mathrm{IC}_{50}=115.60 \mu \mathrm{g} \mathrm{ml}{ }^{-1}\right)$ while lowest activity was recorded from methanol extract of 'MEM-3' fruits $\left(66.77 \% ; \mathrm{IC}_{50}=245.84 \mu \mathrm{g} \mathrm{ml}{ }^{-1}\right)$. The higher antioxidant activity of $M$. citrifolia could be due to higher contents of phytochemcials which showed strong correlation and presence of other natural antioxidants like flavones, flavonols and proanthocyanidins $[8,18,21]$. The observations for strong correlation between antioxidant activity with phyto-nutrients are in conformity with the previous reports of Katalinic, et al. (2006) and Singh, et al. 
(2012a, 2012b) $[8,18,22]$. The low antioxidant activity of 'MEM-3' will be fruits due to the reasons: First, it has been reported that reaction of DPPH with certain phenols such as eugenol and its derivatives is reversible, resulting in low readings for antioxidant activity (\% disappearance). The second possible reason could be due to the slow rate of the reaction between DPPH and the substrate molecules $[23,24]$.

\section{Proximate composition}

The proximate analysis of fruits of 33 genotypes of $M$. citrifolia also supported wide range diversity as presented in Table 2. Fruit juice recovery affected by various factors and present study revealed wide variation among the test genotypes. It was highest in 'HD-6A' (65.5 \%) while lowest in 'MEM-1' (22.4\%). Breeding for higher recovery of crude fibre from Morinda citrofolia was big challenge and present study identified source genotypes as 'MEM-1' (9.97 \%) and 'BRJ-19' (7.62 \%). Fresh fruits of M. citrifolia are poor in fat content which ranged from $0.09 \%$ in 'JGH-5' to $0.24 \%$ 'MANJ-1' (Table 2) [5]. The study showed possibilities for selection of appropriate genotypes in $M$. citrifolia for protein as 'FRG-14' (6.0\%) and 'MANJ-9 (2.9\%); total soluble solids like 'ABH-1' (9.8 Brix); 'CHLD-17' (0.41\%) for titrable acidity and 'LH-1' (930.4 mg/100 g) for carbohydrate recovery.

\begin{tabular}{|c|c|c|c|c|c|c|c|c|c|c|c|}
\hline Genotypes* & Juice (\%) & $\begin{array}{c}\text { Crude } \\
\text { fiber (\%) }\end{array}$ & Fat $(\%)$ & $\begin{array}{c}\text { Protein } \\
(\%)\end{array}$ & $\begin{array}{c}\text { TSS } \\
\left({ }^{\circ} \text { Brix }\right)\end{array}$ & $\begin{array}{c}\text { Acidity } \\
(\%)\end{array}$ & $\begin{array}{c}\text { Carbohy- } \\
\text { drate } \\
(\mathrm{mg} / 100 \mathrm{~g})\end{array}$ & Mn & $\mathrm{Ca}$ & $\mathrm{Cu}$ & Mg \\
\hline Average & 9.2 & 0.6 & 0.05 & 0.7 & 1.1 & 0.1 & 181.9 & 68.6 & 2534.8 & 2.9 & 378.7 \\
\hline STDEV & 36.2 & 8.6 & 0.2 & 4.5 & 7.8 & 0.2 & 653.7 & 88.9 & 2279.2 & 8.2 & 507.8 \\
\hline Range & $9.2-65.5$ & $0.6-10$ & $0.05-0.2$ & $0.7-6.0$ & $1.1-9.8$ & $0.1-0.4$ & $\begin{array}{c}181.9- \\
930.4\end{array}$ & $4.6-284.2$ & $\begin{array}{c}51.1- \\
6815.6\end{array}$ & $2.9-17.2$ & $\begin{array}{c}16.3- \\
1131.3\end{array}$ \\
\hline
\end{tabular}

Table 2: Statistical analysis of diversity in proximate and micronutrients contents in Morinda citrifolia L. genotype

\section{Anti-nutritional factors}

Anti-nutrients analysis in fruits of 33 genotypes of $M$. citrifolia showed the highest nitrate content in 'HD-6' (98.8 mg/100 g) and lowest in 'MEM-3' (22.23 mg/100 g). Phytate was ranged from 185.0 (TRA-1) to $967.9 \mathrm{mg} / 100 \mathrm{~g}$ (CHTAP-13) while oxalate content was highest in 'ABF-1' (67.05 mg/100 g). Saponin content was high in M. citrifolia genotypes and observed in the ranged of 130 to $440 \mathrm{mg} / 100 \mathrm{~g}$, lowest in 'LH-1' and highest in 'LH-12'. The genotypes low in anti-nutrients were identified as 'MHP-19', 'FF-8' and 'MEM-2' for nitrate; 'JGH-5', 'MEM-1', 'CHLD-17' and 'TRA-1' for phytate; 'MANJ-9', 'MBAY-16' and 'LH-' for oxalate and 'TRA1', 'HD-6' and 'TRA-2' for saponin. Though, $M$. citrifolia is rarely consumed as fresh salted fruits, roasted fruits or vegetables but high concentration of anti-nutritive factors in fresh fruits is concern for consumers, thus, genotypes low in anti-nutrients should be used for food purpose. The promising genotypes identified for various phyto-nutrients such as 'GAH-1', 'CHTAP-13', 'TRA1' and 'TRA-2' given in Table 3 could be used in breeding programme or recovery of higher phytochemicals in herbal products.

\begin{tabular}{|c|c|c|}
\hline & Constituents & Promising genotypes \\
\hline \multirow{7}{*}{ Proximates } & Juice (\%) & HD-6A (65.5), HD-6 (60.3), HBAY-11 (45.6), ABF-1 (43.3) \\
\hline & $\begin{array}{c}\text { Crude fiber } \\
(\%)\end{array}$ & MEM-1 (10.0), ABH-1 (9.9), WAND-4 (9.8), MEM-3 (9.6) \\
\hline & Fat $(\%)$ & ABF-1 (0.24), ABF-2 (0.23), AHD-1 (0.22), BRJ-19 (0.22) \\
\hline & Protein $(\%)$ & FRG-14 (6.0), ABF-1 (5.5), MEM-1 (5.5), BRJ-19 (5.4) \\
\hline & Acidity (\%) & CHLD-17 (0.4), HD-6A (0.4), CHTAP-13 (0.3), FRG-14 (0.3) \\
\hline & $\begin{array}{c}\mathrm{CHO} \\
(\mathrm{mg} / 100 \mathrm{~g})\end{array}$ & LH-1 (930.4), HD-6A (866.9), ABF-2 (861.8) \\
\hline & TSS ( ${ }^{\circ}$ Brix) & ABH-1 (9.8), TRA-1 (9.5), MEM-1 (9.2), TRA-2 (9.2) \\
\hline \multirow{4}{*}{$\begin{array}{l}\text { Micronutrients } \\
(\mathrm{mg} / \mathrm{100g})\end{array}$} & $\mathrm{Mn}$ & SPG-2 (284.2), JGH-1 (248.2), ABF-2 (205.4), ABF-1 (185.2) \\
\hline & $\mathrm{Cu}$ & PBAY-7 (17.2), LH-1 (13.4), ABF-1 (12.2), SPG-2 (12.1) \\
\hline & $\mathrm{Ca}$ & MBAY-16 (6815.6), MHP-19 (6722.7), HBAY-11 (6651.6) \\
\hline & $\mathrm{Mg}$ & AHD-1 (1131.3), JGH-1 (1121.2), ABH-1 (1114.1) \\
\hline \multirow{7}{*}{$\begin{array}{l}\text { Antioxidants } \\
(\mathrm{mg} / \mathrm{100g})\end{array}$} & Polyphenol & TRA-1 (370.3), CHTAP-13 (365.9), HD-6 (365.2), HD-6A (347.0) \\
\hline & Flavonoid & JGH-5 (656.2), TRA-1 (614.0), PBAY-7 (599.4), TRA-2 ((588.2) \\
\hline & Anthocyanin & MANJ-1 (340.4), ABF-2 (326.5), ABF-1 (303.9), AHD-1 (290.9) \\
\hline & Tannin & HD-6 (395.2), TRA-1 (390.6), CHTAP-13 (380.4), HD-6A (361.3) \\
\hline & Carotenoid & LH-12 (696.3), AHD-1 (678.8), TRA-2 (663.4), MEM-2 (618.9) \\
\hline & Ascorbic acid & GAH-1 (98.2), TRA-2 (94.9), TRA-1 (93.5), JGH-1 (91.8) \\
\hline & $\begin{array}{l}\text { DPPH activity } \\
(\%)\end{array}$ & FRG-14 (88.6), HBAY-11A (83.0), WAND-4 (82.5), TRA-1 (82.4) \\
\hline
\end{tabular}




\begin{tabular}{|c|c|c|}
\hline & Constituents & Promising genotypes \\
\hline \multirow{4}{*}{$\begin{array}{c}\text { Anti-nutrients } \\
(\mathrm{mg} / \mathbf{1 0 0 g})\end{array}$} & Saponin & LH-12 (440.0), CHLD-17 (435.0), PBAY-7 (415.0) \\
\hline & Phytate & CHTAP-13 (968.0), ABH-1 (953.8), HD-6A (911.0), JGH-1 (896.8) \\
\hline & Nitrate & HD-6 (98.8), TRA-1 (97.7), CHTAP-13 (95.1), HD-6A (90.3) \\
\hline & Oxalate & ABF-1 (67.1), GAH-1 (62.8), CHTAP-13 (62.6), CAL-10 (60.3) \\
\hline
\end{tabular}

\section{Micronutrients}

The analyses of micronutrient estimation in 33 genotypes of $M$. citrifolia are presented in Table 2. Manganese content was observed to highest in 'SPG-2' (284.2 ppm) while lowest in 'ABH-1' (4.6 ppm). M. citrifolia genotypes showed great variation for calcium content in fruits which ranged from $51.1 \mathrm{ppm}$ in 'GAH-1' to $6815.6 \mathrm{ppm}$ 'MBAY-16'. Similarly, Mg in M. citrifolia fruits was ranged from $16.3 \mathrm{ppm}$ ('GAH-2') to $1131.3 \mathrm{ppm}$ ('AHD-1'). However, M. citrifolia was observed to be poor in copper content as it ranged from 2.9 to $17.2 \mathrm{ppm}$, highest in 'PBAY-7' and minimum in 'MHP-19'.

\section{Correlation and regression studies}

The results for correlation and regression analysis of phytochemical contents in $M$. citrifolia germplasm are presented in Table 4. The DPPH antioxidant activity of methanol extract of fruits showed good correlation with carotenoids $\left(\mathrm{r}^{2}=0.335 ; \mathrm{p}<0.05\right)$ and flavonoids $\left(\mathrm{r}^{2}=0.249 ; \mathrm{p}<0.05\right)$. Interestingly, the present study revealed strong correlation between antioxidant activity and Cu $\left(\mathrm{r}^{2}=0.953 ; \mathrm{p}<0.05\right), \mathrm{Mn}\left(\mathrm{r}^{2}=0.953 ; \mathrm{p}<0.05\right)$ and $\mathrm{Mg}\left(\mathrm{r}^{2}=0.582 ; \mathrm{p}<0.05\right)$. However, Ca content also showed good correlation with antioxidant activity $\left(\mathrm{r}^{2}=0.220 ; \mathrm{p}<0.05\right)$. Among phytochemicals, the carotenoids content in $M$. citrifolia germplasm showed strong correlation with ascorbic acid $\left(r^{2}=0.973 ; p<0.05\right)$, tannin $\left(r^{2}=0.598 ; p<0.05\right)$, flavonoids $\left(\left(r^{2}=0.691 ; p<0.05\right)\right.$ and $p h e n o l\left(r^{2}=0.598\right.$; $\mathrm{p}<0.05)$. The correlation analysis between phytochemicals and micronutrients revealed strong positive correlation viz., flavonoids and $\mathrm{Mn}\left(\mathrm{r}^{2}=0.902 ; \mathrm{p}<0.05\right)$; tannin and $\mathrm{Cu}\left(\mathrm{r}^{2}=0.916 ; \mathrm{p}<0.05\right)$ carotenoids and $\mathrm{Mg}\left(\mathrm{r}^{2}=0.553 ; \mathrm{p}<0.05\right)$.

\begin{tabular}{|c|c|c|c|c|c|c|c|c|c|c|c|c|}
\hline Parameters & $\begin{array}{c}\text { DPPH } \\
\text { activity }\end{array}$ & Phenol & $\begin{array}{c}\text { Flavo- } \\
\text { noids }\end{array}$ & Tannin & $\begin{array}{l}\text { Carot- } \\
\text { enoids }\end{array}$ & $\begin{array}{l}\text { Ascorbic } \\
\text { acid }\end{array}$ & Mn & $\mathrm{Ca}$ & $\mathrm{Cu}$ & Mg & $\begin{array}{l}\text { Eigen } \\
\text { value }\end{array}$ & $\begin{array}{c}\% \text { vari- } \\
\text { ance }\end{array}$ \\
\hline $\begin{array}{c}\text { DPPH } \\
\text { activity }\end{array}$ & 1.00 & 0.010 & 0.249 & 0.012 & 0.335 & 0.013 & 0.912 & 0.220 & 0.953 & 0.982 & 3.3 & 33.3 \\
\hline Phenol & & 1.000 & 0.220 & 0.000 & 0.598 & 0.001 & 0.173 & 0.029 & 0.458 & 0.153 & 2.0 & 19.7 \\
\hline Flavonoids & & & 1.000 & 0.197 & 0.691 & 0.397 & 0.902 & 0.398 & 0.553 & 0.249 & 1.3 & 12.5 \\
\hline Tannin & & & & 1.000 & 0.809 & 0.023 & 0.626 & 0.194 & 0.916 & 0.569 & 1.0 & 10.0 \\
\hline $\begin{array}{c}\text { Caroteno- } \\
\text { ids }\end{array}$ & & & & & 1.000 & 0.973 & 0.555 & 0.437 & 0.346 & 0.553 & 0.8 & 7.8 \\
\hline $\begin{array}{l}\text { Ascorbic } \\
\text { acid }\end{array}$ & & & & & & 1.000 & 0.110 & 0.000 & 0.183 & 0.310 & 0.6 & 5.9 \\
\hline Mn & & & & & & & 1.000 & 0.039 & 0.001 & 0.000 & 0.4 & 4.0 \\
\hline $\mathrm{Ca}$ & & & & & & & & 1.000 & 0.035 & 0.081 & 0.3 & 3.3 \\
\hline $\mathrm{Cu}$ & & & & & & & & & 1.000 & 0.013 & 0.3 & 2.7 \\
\hline $\mathrm{Mg}$ & & & & & & & & & & 1.000 & 0.1 & 0.7 \\
\hline
\end{tabular}

Table 4: Correlation between antioxidant and phytonutrients M. citrifolia L

\section{Conclusion}

The present study is an attempt to investigate the genetic influence on phytochemistry of Morinda citrifolia using 33 collections from Andaman Islands. The significant $(\mathrm{p}<0.05)$ variations in dietary micronutrients, potential antioxidants and antioxidant activity suggest that phytochemical composition affected by the genotypes and also identified potential genotypes for further use in breeding or food schemes. The identified genotypes could help in further breeding programme, study of biochemical pathways in Morinda citrifolia or higher recovery of phyto-nutrient in its herbal products.

\section{Acknowledgement}

The authors acknowledge the financial support of National Medicinal Plant Board, New Delhi and Director Central Island Agricultural Research Institute, Port Blair for providing the research facilities. The contribution of plant materials by the local farmers/tribes to the germplasm was also acknowledged by the authors.

\section{References}

1. Singh HP, Singh DR, Srivastava RC (2009) The Devine Noni (Morinda citrifolia L.), CARI, Port Blair, India.

2. Singh DR, Singh S (2013b) Morinda citrifolia (Noni): a fruit of future for its nutritional, phytochemical and biological properties. Asian agri history 17: 141-55. 
3. Singh DR, Singh S, Srivastava RC (2010) Noni (Morinda citrifolia L.), In K.V. Peter (ed) Future crops Vol. I, Daya Publishing House, New Delhi, India.

4. McClatchey W (2002) From Polynesian healers to health food stores: changing perspectives of Morinda citrifolia (Rubiaceae). Integr Cancer Ther 1: 110-20.

5. Singh DR, Singh S, Shrawan, (2013a) Noni In: Fruit Production in India W. S. Dillon(ed). Narendra Publishing House, New Delhi, India.

6. Wang MY, West BJ, Jensen CJ, Nowicki D, Su C, et al. (2002) Morinda citrifolia (Noni): a literature review and recent advances in Noni research. Acta Pharmacol Sin 23: $1127-41$.

7. Rethinam P, Sivaraman K (2007) Noni (Morinda citrifolia L) the Miracle Fruit - A Holistic Review. Int J Noni Res 1: 4-37.

8. Singh DR, Singh S, Salim KM, Srivastava RC (2012a) Estimation of phytochemicals and antioxidant activity of underutilized fruits of Andaman Islands (India). Int J Food Sci Nutr 63: 446-52.

9. Singh DR, Singh S, Minj D, Anbananthan V, Salim KM, et al. (2012) Diversity of Morinda citrifolia L. in Andaman and Nicobar Islands (India): assessed through morphological and DNA markers. African J Biotech 11: 15214-25.

10. Waki J, Okpul T, Komolong M (2007) A descriptor list for morphological characterization of Noni (Morinda citrifolia L). South Paci J Natur Sci 10: 61-6.

11. Chang CC, Yang MH, Wen HM, Chern JC (2002) Estimation of total flavonoid content in propolis by two complementary colorimetric methods. J Food Drug Anal 10: 178-82.

12. Singleton V L, Rossi JA (1965) Colorimetry of total phenolics with phosphomolybdic-phosphotungstic acid reagents. Am J Enol Vitic 16: 144-58.

13. Fuleki T, Francis FJ (1968) Quantitative methods for anthocyanin extraction and determination of total anthocyanin in cranberries. J Food Sci 33: $72-7$.

14. Sadasivam S, Manickam A (1992) Biochemical methods for Agricultural Sciences. Wiley Eastern Ltd, New Delhi 187-90.

15. Sadasivam S, Manikam A (1996) Hand book of biochemical methods. Madras: Wiley Eastern Ltd 246-8.

16. Hassan LG, Dangoggo SM, Umar KJ, Saidu I, Folorunsho FA (2008) Proximate, minerals and antinutritional factors of Daniellia oliveri seed kernel. Chem Class J 5: 31-6.

17. Cunniff P (1995) Official Methods of Analysis. Association of Official Analytical Chemists, Washington, DC.

18. Singh S, Singh DR, Salim KM, Srivastava A, Singh LB, et al. (2011) Estimation of proximate composition, micronutrients and phytochemical compounds in traditional vegetables from Andaman and Nicobar Islands. Int J Food Sci Nutr 62: 765-73.

19. Singh DR, Srivastava AK, Srivastava A, Srivastava RC (2011a) Genetic diversity among three Morinda species using RAPD and ISSR markers. Indian J Biotech 10: 285-93.

20. Pichersky E, Gang DR (2000) Genetics and biochemistry of secondary metabolites in plants: an evolutionary perspective. Trends Plant Sci 5: 439-45.

21. Skerget M, Kotnik P, Hadolin M, Hras AR, Simonic M, et al. (2005) Phenols, proanthocyanidins, flavones and flavonols in some plant materials and their antioxidant activities. Food Chem 89: 191-98.

22. Katalinic V, Milos M, Kusilic T, Jukic M (2006) Screening of 70 medicinal plant extracts for antioxidant capacity and total phenols. Food Chem $94: 550-7$.

23. Huang D, Ou B, Prior RL (2005) The chemistry behind antioxidant capacity assays. J Agric Food Chem 53: 1841-56.

24. Bondet V, Brand Williams W, Berset C (1997) Kinetics and Mechanisms of Antioxidant Activity using the DPPH.Free Radical Method. LWT - Food Sci and Tech 30: 609-15. 